\title{
Interaction between cadmium and atrazine during uptake by rice seedlings (Oryza sativa L.)
}

\author{
Yu-Hong $\mathrm{Su}^{\mathrm{a}, \mathrm{b}}$, Yong-Guan Zhu ${ }^{\mathrm{a}, *}$, Ai-Jun Lin ${ }^{\mathrm{a}}$, Xu-Hong Zhang ${ }^{\mathrm{a}}$ \\ ${ }^{a}$ Research Center for Eco-environmental Sciences, Chinese Academy of Sciences, Beijing 100085, China \\ ${ }^{\mathrm{b}}$ Department of Chemistry, Xinjiang University, Urumqi 830046, China
}

Available online 4 June 2005

\begin{abstract}
The uptake of atrazine by rice seedlings (Oryza sativa L.) through plant roots from nutrient solution was investigated in the presence and absence of $\mathrm{Cd}^{2+}$ over an exposure period of four weeks. It was found that both atrazine and $\mathrm{Cd}^{2+}$ were toxic to rice seedlings. Both shoot and root biomasses decreased when the seedlings were exposed to increasing atrazine or $\mathrm{Cd}^{2+}$ concentrations in nutrient solutions. In the absence of $\mathrm{Cd}^{2+}$, a linear relationship was observed between atrazine concentrations in roots/shoots and in external solution, and more atrazine is concentrated in roots than in shoots. When atrazine and $\mathrm{Cd}^{2+}$ concentrations in solution were maintained at mole ratio of $1: 1$, the accumulation of atrazine by seedlings was less and the seedling biomass was greater than found with other ratios, such as 1:2 or 2:1. Therefore, the formation of the complex between atrazine and $\mathrm{Cd}^{2+}$ reduced the individual toxicities. Analyses of data with the quasi-equilibrium partition model indicated that the atrazine concentrations in rice seedlings and external water were close to equilibrium. In the presence of $\mathrm{Cd}^{2+}$, however, the measured bioconcentration factor (BCF) of atrazine with roots and shoots were considerably greater. The latter findings resulted presumably from the atrazine- $\mathrm{Cd}^{2+}$ complex formation that led to a large apparent BCF.
\end{abstract}

(c) 2005 Elsevier Ltd. All rights reserved.

Keywords: Atrazine; Cadmium; Rice seedlings; Uptake; Bioconcentration factor

\section{Introduction}

There has been a considerable interest in understanding the uptake of organic contaminants by plants during the last two decades (Briggs et al., 1982; Trapp and Matthies, 1995; Weiss, 2000; Chiou et al., 2001; Li et al., 2002; Trapp, 2004). Plants could be exposed to contaminants in different ways. Organic contaminants may enter plant roots by passive and/or active processes and

\footnotetext{
* Corresponding author. Tel.: +86106293 6940; fax: +8610 62923563.

E-mail address: ygzhu@mail.rcees.ac.cn (Y.-G. Zhu).
}

then translocate with plant transpiration stream to other plant components (Briggs et al., 1982; Chiou et al., 2001; Trapp, 2004). Passive transport, which proceeds in the direction of decreasing chemical potential, consists of a series of partitions between plant water and plant organic matter within various plant components (Chiou et al., 2001). It has been found to be largely responsible for the uptake of nonionic compounds (Briggs et al., 1982; Chiou et al., 2001). Active transport, which may proceed against the chemical potential gradient, occurs for certain nutrients and other (inorganic and organic) ions (Trapp, 2004).

Atrazine is a member of the triazine-herbicide family, used widely in agriculture and commonly found as a 
pollutant in soil and (ground) water (Belluck et al., 1991; Burkart and Kolpin, 1993). It has become a special concern due to its large quantity of use and potential for transport and accumulation. The risk of atrazine to the exposed population included acute and chronic health effects, as well as an increased risk in cancer (Sielken, 1987; Bennett et al., 1999). Earlier reports indicate that atrazine might persist for long periods of time in soil and groundwater (McKone and Bogen, 1991; Finley et al., 1994; Gu et al., 2003). As a herbicide, atrazine inhibits photosynthesis by displacing the secondary quinone acceptor of the electron transport chain from its binding site (Hirschberg and McIntosh, 1983). Atrazine is commonly applied to fields of corns, sorghums, sugar canes, nut orchards, and macadamias. In China, the atrazine application to rotation fields significantly affects the growth of rice; the rice seedlings may take up great concentrations of atrazine from soils. Cadmium $(\mathrm{Cd})$ is a widely occurring metal pollutant. Emissions of $\mathrm{Cd}$ from human activities have been estimated to be about $30000 \mathrm{t}$ annually (Di Toppi et al., 1998). Soil contamination with $\mathrm{Cd}$ due to irrigation with Cd-contaminated wastewater or to fertilizing and mining/smelting activities poses a long-term risk to humans and animals, which has received increasing attention worldwide. Cadmium is highly toxic to humans as well as plants (McLaughlin and Singh, 1999).

Although numerous papers have dealt with the toxicity and fate of atrazine and $\mathrm{Cd}$ in the environment (Shimabukuoro et al., 1970; Liu et al., 1999; Katz et al., 2000; Wiegand et al., 2000; Zhao et al., 2003), few studies focused on their effects as mixtures. In fact, atrazine contains five electron-donor atoms that could potentially participate in the formation of metal/atrazine complexes. Previous studies (Martin et al., 1998; Meng and Carper, 2000) showed that $\mathrm{Ca}, \mathrm{Mg}, \mathrm{Pb}, \mathrm{Zn}, \mathrm{Cd}$, and $\mathrm{Cu}$ can complex with both monomeric and dimeric atrazine in both anhydrous and hydrated forms (with one or two water molecules). The effect of atrazine-metal complexation on the plant uptake of atrazine and metals must be taken into account to address the biogeochemical cycle of pollutants, since these metals are ubiquitous. In this study, we investigated the atrazine toxicity to and accumulation by rice plants in nutrient solution and the effect of atrazine-Cd association on their individual uptakes by rice seedlings.

\section{Materials and methods}

\subsection{Preparation of rice seedlings}

Seeds of rice, China Giyou-1, were disinfected in $10 \%$ $\mathrm{H}_{2} \mathrm{O}_{2}$ (w:w) solution for $10 \mathrm{~min}$, followed by thorough washing with de-ionized water. The seeds were germinated in moist perlite. After three weeks, uniform seed- lings were selected and transplanted to PVC pots (7.5$\mathrm{cm}$ diameter and 14-cm high, one plant per pot) containing $500 \mathrm{ml}$ nutrient solution. The compositions of nutrient solutions for uptake studies of atrazine (ATR) and $\mathrm{Cd}$ as single and in mixture were as follows: $5 \mathrm{mM}$ $\mathrm{NH}_{4} \mathrm{NO}_{3}, 12 \mathrm{mM} \mathrm{KH}{ }_{2} \mathrm{PO}_{4}, 2 \mathrm{mM} \mathrm{K}_{2} \mathrm{SO}_{4}, 4 \mathrm{mM} \mathrm{CaCl}_{2}$, $1.5 \mathrm{mM} \mathrm{MgSO}_{4}, 100 \mu \mathrm{M} \mathrm{Fe}(\mathrm{III})$-ethylenediaminetetraacetic acid (EDTA), $10 \mu \mathrm{M} \mathrm{H}{ }_{3} \mathrm{BO}_{4}, 1.0 \mu \mathrm{M} \mathrm{ZnSO}$, $1.0 \mu \mathrm{M} \mathrm{CuSO}{ }_{4}, 5.0 \mu \mathrm{M} \mathrm{MnSO}_{4}, 0.5 \mu \mathrm{M} \mathrm{Na}_{2} \mathrm{MoO}_{4}$, and $0.2 \mu \mathrm{M} \mathrm{CoSO}_{4}$. The nutrient solution was a modification of Long Ashton Formula after Zhu et al. (1999) with the $\mathrm{pH}$ maintained at $5.5 \mathrm{using} 0.1 \mathrm{M} \mathrm{KOH}$ or $\mathrm{HCl}$ solution (Trostle et al., 2001). The seedlings were allowed to grow in the nutrient solution for one week before use for uptake studies.

\subsection{Treatments with atrazine and $C d$}

Chemicals used for plant uptake, such as $\mathrm{Cd}\left(\mathrm{NO}_{3}\right)_{2}$, $\mathrm{CaCl}_{2}, \mathrm{NH}_{4} \mathrm{NO}_{3}$, were all of analytical grade; ATR was provided by Chem. Service, Inc. The purities of all chemicals are more than $98 \%$. In Series 1 experiment, rice seedlings were exposed to nutrient solutions with initial ATR concentrations at $0,0.5,1.0$, and $2.0 \mu \mathrm{M}$ without added Cd. In Series 2 experiment, seedlings were exposed to nutrient solutions with initial concentration of ATR at $0,0.5$, and $1.0 \mu \mathrm{M}$ and $\mathrm{Cd}^{2+}$ [as $\mathrm{Cd}\left(\mathrm{NO}_{3}\right)_{2}$ ] at $0.5 \mu \mathrm{M}$. In Series 3 experiment, seedlings were exposed to nutrient solutions with initial concentration of ATR at $0,0.5$, and $1.0 \mu \mathrm{M}$ and $\mathrm{Cd}^{2+}$ [as $\mathrm{Cd}\left(\mathrm{NO}_{3}\right)_{2}$ ] at $1.0 \mu \mathrm{M}$. Each treatment was conducted with four replicates. The exposure periods for all these series were four weeks. Nutrient solutions with corresponding ATR and/or $\mathrm{Cd}^{2+}$ concentrations were replaced twice per week. Near the end of this four-week exposure period, the added ATR or Cd concentrations in nutrient solutions stayed largely unchanged with time, i.e., the concentrations in solutions and seedlings were essentially at equilibrium. The experiments were carried out in a controlled environment growth chamber with a 14-h light period $\left(260-350 \mu \mathrm{mol} \mathrm{m}^{-2} \mathrm{~s}^{-1}\right)$ and temperatures of $25^{\circ} \mathrm{C}$ day and $20^{\circ} \mathrm{C}$ night. The relative humidity was $70 \%$.

\subsection{Analyses of contaminants with plants}

\subsubsection{Harvest}

After plants were harvested, they were washed with deionized water and blotted dry, and then sectioned into roots and shoots. Fresh weights of both roots and shoots were recorded immediately. In the treatments with ATR, fresh subsamples (0.6-2.6 g) were taken for ATR analysis, the rest were dried in an oven at $70^{\circ} \mathrm{C}$ for $48 \mathrm{~h}$ and the dry weights were recorded. Plant water contents $\left(f_{\mathrm{pw}}\right)$ and organic-matter contents $\left(f_{\mathrm{pom}}\right)$ were determined accordingly. 


\subsection{2. $C d$ analysis}

The dried plant material was ground and a weighed amount of sample (about $0.25 \mathrm{~g}$ ) was placed into clean, dry Teflon tubes for digestion $(100 \mathrm{ml})(\mathrm{CEM}$ digestion tubes). Concentrated $\mathrm{HNO}_{3}(5 \mathrm{ml})$ was added. The tubes were placed on a microwave-accelerated reaction system (Mars5, CEM microwave Technology Ltd.). The sample digestion was conducted with $15 \mathrm{~min}$ ramping to $160^{\circ} \mathrm{C}$, with a continuous holding at this temperature for $15 \mathrm{~min}$. Reagent blanks with standard reference plant material (GBW07603 from the National Research Center for Standards in China) were used to verify the accuracy and precision of the digestion procedure and the subsequent analysis. After digestion, the solutions were cooled, diluted to $50 \mathrm{ml}$ with ultra-pure water (Easy-pure, Dubugue, Iowa, USA) and transferred into acid-washed plastic bottles. Concentrations of $\mathrm{Cd}$ in acid digests were quantified with a Hitachi 6100 Atomic Absorption Spectroscopy (Hitachi- 6100, Japan).

\subsubsection{Atrazine analysis}

Both solution and fresh plant samples were extracted for ATR analysis. The nutrient solution $(1.00 \mathrm{ml})$ was extracted using $2.00 \mathrm{ml}$ of hexanes. The plant samples (shoots and roots), 0.6-2.6 $\mathrm{g}$ in fresh weight, were rinsed with distilled water four times to remove residual ATR on seedling surfaces, wiped with tissue paper, and immediately weighed. The samples were cut up with a pair of scissors, homogenized using a mortar and pestle, and then extracted utilizing an ultrasonic crusher machine with $40 \mathrm{ml}$ of mixed methanol and water (1:1, v:v). The liquid phase was filtrated and collected. The samples were then extracted three times with $10 \mathrm{ml}$ of fresh mixed solvents. The liquid phases from all extractions were combined and extracted with $20 \mathrm{ml}$ of petroleum ether mixed with dichloromethane (6.5:3.5, v:v). Supernatants of the mixed-solvent phase were passed through anhydrous $\mathrm{Na}_{2} \mathrm{SO}_{4}$ columns and collected. This procedure was repeated four times. The eluates were combined, concentrated into a small volume $(1-2 \mathrm{ml})$ using a rotary evaporator (Senco, China) with a gentle stream of dry nitrogen, solvated again with $30 \mathrm{ml}$ petroleum ether, and extracted three times with $20 \mathrm{ml}$ of acetoni- trile. The acetonitrile fractions were combined, concentrated, and evaporated. The residues were solvated with petroleum ether and cleaned with Florisil column. The concentrations of ATR in extracts were analyzed with an Agilent 6820 gas chromatograph equipped with a ${ }^{63} \mathrm{Ni}$ electron capture detector (ECD) using a HP-5 capillary column $(0.32 \mathrm{~mm} \times 30 \mathrm{~m}, 0.25 \mu \mathrm{m}$ film thickness). Peak areas representing ATR were quantified with external standards for determining the ATR concentrations. The average recoveries of atrazine were 83.9-96.6\% $(n=5)$ for spiked plant samples and 97.6$103.7 \%(n=5)$ for spiked solution.

\subsection{Data analysis}

Analysis of variance (ANOVA) was performed using Genstat for Windows on a personal computer (NAG Ltd, England). Two-way analysis of variance was carried out on atrazine and cadmium uptake.

\section{Results and discussion}

\subsection{Plant biomass}

In general, the biomasses of seedling roots and shoots were reduced more strongly by ATR concentrations in growth solution; the presence of $\mathrm{Cd}^{2+}$ either alone or in $\mathrm{Cd}^{2+}$-ATR mixtures in solution showed only a small effect (decrease or increase) on root and shoot biomasses (Table 1). For example, seedlings exposed to $\mathrm{Cd}^{2+}$ in nutrient solution without ATR showed 30\% reduction in root biomass and $11 \%$ reduction in shoot biomass at $\mathrm{Cd}^{2+}$ concentrations of $1.0 \mu \mathrm{M}$ relative to control plants. For seedlings exposed to ATR without $\mathrm{Cd}^{2+}$, the biomasses of shoots and roots showed $39 \%$ and $54 \%$ reductions, respectively, at ATR concentrations of $1.0 \mu \mathrm{M}$. For plants exposed to mixtures of $\mathrm{Cd}^{2+}$ and ATR in nutrient solutions, the shoot and root biomasses either increased or decreased to a small extent depending on the systems. For example, when ATR concentrations were kept at $0.5 \mu \mathrm{M}$, the root and shoot biomasses were greater with $\mathrm{Cd}^{2+}$ at $0.5 \mu \mathrm{M}$ than those at $1.0 \mu \mathrm{M}$;

Table 1

Biomasses ( $\mathrm{g}$ dry matter) of rice seedlings exposed to various concentrations of atrazine (ATR, $\mu \mathrm{M})$ and cadmium $(\mathrm{Cd}, \mu \mathrm{M})$ in nutrient solution (mean $\pm \mathrm{SE}, n=4$ )

\begin{tabular}{|c|c|c|c|c|c|c|}
\hline \multirow[t]{2}{*}{ Atrazine concentrations } & \multicolumn{3}{|c|}{$\begin{array}{l}\text { Root biomass } \\
\text { Cd concentrations }\end{array}$} & \multicolumn{3}{|c|}{$\begin{array}{l}\text { Shoot biomass } \\
\text { Cd concentrations }\end{array}$} \\
\hline & 0.0 & 0.5 & 1.0 & 0.0 & 0.5 & 1.0 \\
\hline 0.0 & $0.15 \pm 0.02$ & $0.12 \pm 0.01$ & $0.10 \pm 0.01$ & $0.54 \pm 0.03$ & $0.51 \pm 0.02$ & $0.48 \pm 0.05$ \\
\hline 0.5 & $0.11 \pm 0.01$ & $0.13 \pm 0.02$ & $0.12 \pm 0.01$ & $0.53 \pm 0.02$ & $0.53 \pm 0.05$ & $0.44 \pm 0.03$ \\
\hline 1.0 & $0.07 \pm 0.01$ & $0.09 \pm 0.01$ & $0.12 \pm 0.01$ & $0.33 \pm 0.03$ & $0.36 \pm 0.02$ & $0.45 \pm 0.04$ \\
\hline 2.0 & $0.03 \pm 0.00$ & - & - & $0.15 \pm 0.02$ & - & - \\
\hline
\end{tabular}


similarly, when ATR concentrations were kept at $1.0 \mu \mathrm{M}$, the biomasses were greater with $\mathrm{Cd}^{2+}$ at $1.0 \mu \mathrm{M}$ than at $0.5 \mu \mathrm{M}$. Results indicate that ratios of $\mathrm{Cd}$ and ATR play an essential role in their effects on the seedling growth.

\subsection{Atrazine uptake}

The observed ATR concentrations in seedlings (roots and shoots) were considerably higher than those in external solution. Good linear relationships were observed between ATR concentrations in roots/shoots and external solution, as depicted in Fig. 1. The presence of $\mathrm{Cd}^{2+}$ in the nutrient solution increased generally by a great amount the concentrations of ATR in roots and shoots. For instance, for plants exposed to low ATR concentrations at $0.5 \mu \mathrm{M}$, the ATR concentrations in shoots and roots increased $79 \%$ and $256 \%$, respectively, when the $\mathrm{Cd}^{2+}$ concentration increased to $1.0 \mu \mathrm{M}$ (Table

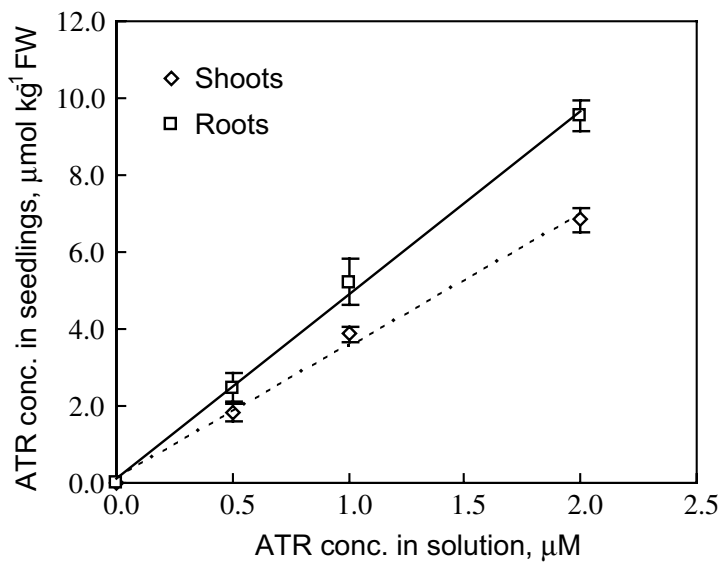

Fig. 1. ATR uptake by rice seedlings from nutrient solution in the absence of $\mathrm{Cd}$. Each point is the mean of four replicates. Error bars represent the standard errors (SE).
2 and Fig. 2). For plants exposed to high ATR concentrations at $1.0 \mu \mathrm{M}$, the ATR concentrations in shoots and roots increased $16 \%$ and $52 \%$ with $\mathrm{Cd}^{2+}$ at $1.0 \mu \mathrm{M}$ and $135 \%$ and $164 \%$ with $\mathrm{Cd}^{2+}$ at $0.5 \mu \mathrm{M}$. These results indicate that ratios of $\mathrm{Cd}^{2+}$ and ATR in solution played a significant role in the seedling uptake of ATR, especially for the shoots. In general, when the ATR $-\mathrm{Cd}^{2+}$ ratios in solution were 1 , the enhancing effect of $\mathrm{Cd}^{2+}$ on the ATR concentrations in both shoots and roots were lower than when the ratios were either greater or less than 1 (e.g., 2 or 1/2). In series-1 experiments (i.e., without $\mathrm{Cd}^{2+}$ ), the ATR concentrations in roots were higher than those in shoots, and the concentrations in shoots/ roots were very linearly related to the corresponding ATR concentrations in nutrient solutions.

\subsection{Cadmium uptake}

The $\mathrm{Cd}^{2+}$ concentrations in plants (roots and shoots) increased largely with increasing ATR concentration in nutrient solution, but the enhancing effect of ATR on the $\mathrm{Cd}^{2+}$ concentrations in plants is less marked than that of $\mathrm{Cd}^{2+}$ on the ATR concentration in plants. With low $\mathrm{Cd}^{2+}$ concentrations at $0.5 \mu \mathrm{M}$ in solution, the $\mathrm{Cd}^{2+}$ concentrations in roots and shoots increased $34 \%$ and 93\%, respectively, when the ATR concentration in solution increased from 0.5 to $1.0 \mu \mathrm{M}$ (Table 3). However, with high $\mathrm{Cd}^{2+}$ concentrations (i.e., $1.0 \mu \mathrm{M}$ ) in solution, the $\mathrm{Cd}^{2+}$ concentrations in roots and shoots increased only $15 \%$ and $19 \%$ when the ATR concentration increased from 0.5 to $1.0 \mu \mathrm{M}$. The promotion of $\mathrm{Cd}$ uptake by ATR is somewhat more with shoots than with roots.

\subsection{Discussion}

The present data show that ATR is highly toxic to rice plants; the biomasses of shoots and roots decrease with increasing ATR concentration in nutrient solution

Table 2

ATR concentrations ( $\mu \mathrm{mol} \mathrm{kg}{ }^{-1}$ fresh weight) in rice seedlings exposed to various concentrations of ATR $(\mu \mathrm{M})$ and Cd $(\mu \mathrm{M})$ in nutrient solution (mean $\pm \mathrm{SE}, n=4)$

\begin{tabular}{|c|c|c|c|c|c|c|}
\hline \multirow[t]{2}{*}{$\begin{array}{l}\text { ATR concentrations } \\
\text { in solution }\end{array}$} & \multicolumn{3}{|c|}{$\begin{array}{l}\text { ATR concentrations in roots } \\
\text { Cd concentrations in solution }\end{array}$} & \multicolumn{3}{|c|}{$\begin{array}{l}\text { ATR concentrations in shoots } \\
\text { Cd concentrations in solution }\end{array}$} \\
\hline & 0.0 & 0.5 & 1.0 & 0.0 & 0.5 & 1.0 \\
\hline 0.5 & $2.47 \pm 0.37$ & $5.53 \pm 0.93$ & $8.79 \pm 1.07$ & $1.81 \pm 0.23$ & $2.60 \pm 0.19$ & $3.26 \pm 0.56$ \\
\hline 1.0 & $5.21 \pm 0.60$ & $13.77 \pm 2.98$ & $7.91 \pm 0.88$ & $3.86 \pm 0.19$ & $9.07 \pm 0.65$ & $4.51 \pm 0.56$ \\
\hline \multirow[t]{2}{*}{2.0} & $9.53 \pm 0.42$ & - & - & $6.84 \pm 0.33$ & - & - \\
\hline & \multicolumn{6}{|c|}{ Analysis of variance } \\
\hline $\mathrm{Cd}$ & $* *$ & & & $* * *$ & & \\
\hline ATR & $* * *$ & & & $* * *$ & & \\
\hline $\mathrm{Cd} \times \mathrm{ATR}$ & $* *$ & & & $* * *$ & & \\
\hline
\end{tabular}

$* * * P<0.001 ; * * P<0.01 ; * P<0.05$ (two-way analysis of variance). 

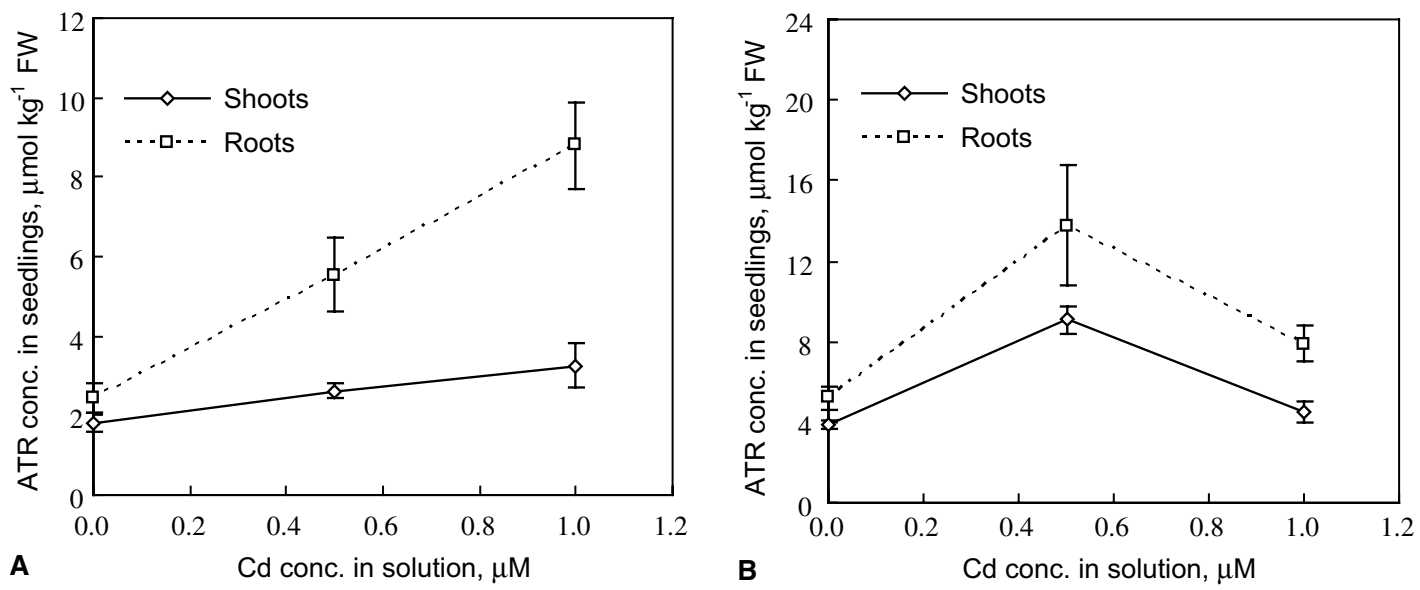

Fig. 2. ATR uptake by rice seedlings from nutrient solution at various Cd concentrations. (A): ATR concentrations in nutrients solution are $0.5 \mu \mathrm{M}$; (B): ATR concentrations in nutrients solution are $1.0 \mu \mathrm{M}$. Each point is the mean of four replicates. Error bars represent the standard errors $(\mathrm{SE})$.

Table 3

Cd concentrations $\left(\mu \mathrm{mol} \mathrm{kg}{ }^{-1}\right.$ fresh weight) in rice seedlings exposed to various concentrations of ATR $(\mu \mathrm{M})$ and $\mathrm{Cd}(\mu \mathrm{M})$ in nutrient solution (mean $\pm \mathrm{SE}, n=4$ )

\begin{tabular}{|c|c|c|c|c|c|c|}
\hline \multirow[t]{2}{*}{$\begin{array}{l}\text { Cd concentrations } \\
\text { in solution }\end{array}$} & \multicolumn{3}{|c|}{$\begin{array}{l}\text { Cd concentrations in roots } \\
\text { ATR concentrations in solution }\end{array}$} & \multicolumn{3}{|c|}{$\begin{array}{l}\text { Cd concentrations in shoots } \\
\text { ATR concentrations in solution }\end{array}$} \\
\hline & 0.0 & 0.5 & 1.0 & 0.0 & 0.5 & 1.0 \\
\hline 0.5 & $495 \pm 13.3$ & $410 \pm 18.8$ & $548 \pm 38.9$ & $68.7 \pm 1.4$ & $59.6 \pm 3.5$ & $115 \pm 13.2$ \\
\hline \multirow[t]{2}{*}{1.0} & $634 \pm 11.5$ & $639 \pm 22.2$ & $734 \pm 28.8$ & $109 \pm 6.0$ & $112 \pm 4.7$ & $137 \pm 12.1$ \\
\hline & \multicolumn{6}{|c|}{ Analysis of variance } \\
\hline $\mathrm{Cd}$ & $* * *$ & & & $* * *$ & & \\
\hline ATR & $*$ & & & $* * *$ & & \\
\hline $\mathrm{Cd} \times \mathrm{ATR}$ & NS & & & NS & & \\
\hline
\end{tabular}

*** $P<0.001 ;{ }^{* *} P<0.01 ; * P<0.05$; NS, not significant (two-way analysis of variance).

(Table 1). The concentrations of ATR in roots are higher than those in shoots, due in part to their different compositions and possibly in part to the more active transformation processes (e.g., volatilization, metabolism, and complex formation) that took place with the shoots.

It is well recognized that the plant uptake of nonionic compounds through roots occurs primarily by passive (partition) process (Briggs et al., 1982; Chiou et al., 2001) and the passive uptake is influenced by the properties of the compounds and plant growth and transpiration rates. The present data showed that the ATR concentrations in seedlings are much greater than those in external solution, as commonly found for chemicals having limited solubility in water (Briggs et al., 1982; Trapp and Matthies, 1995). For the plant uptake of nonionic contaminants in general, the concentration of a contaminant in plants (or in a specific plant part) at a given time can be related to the source concentration in external solution (or soil water) and the quasi-equilibrium factor for the system as calculated by use of Eq. (1) (Chiou et al., 2001):

$$
C_{\mathrm{pt}}=\alpha_{\mathrm{pt}} \quad C_{\mathrm{w}}\left[f_{\mathrm{pw}}+f_{\mathrm{pom}} K_{\mathrm{pom}}\right]
$$

where $C_{\mathrm{pt}}$ is the contaminant concentration in plants on the fresh-weight basis and $C_{\mathrm{w}}$ is the concentration in external water; $f_{\mathrm{pw}}$ and $f_{\text {pom }}$ are the weight fractions of plant water and plant organic matter, respectively; $K_{\text {pom }}$ is the contaminant partition coefficient between plant organic matter and plant water; and $\alpha_{\mathrm{pt}}(\leqslant 1)$ is the quasi-equilibrium factor, the ratio of contaminant concentrations in plant water and external solution at a specific point in time. The ratio of $C_{\mathrm{pt}}$ to $C_{\mathrm{w}}$ is the bioconcentration factor (BCF) of the contaminant. When $\alpha_{\mathrm{pt}}=1$, the contaminant concentrations in plants and external water are at equilibrium; when $\alpha_{\mathrm{pt}}$ is $<1$, it implies the extent of uptake toward the equilibrium limit. 
With the rice seedlings in this study, the measured $f_{\mathrm{pw}}$ and $f_{\text {pom }}$ values for control plants (not exposed to ATR or $\mathrm{Cd}^{2+}$ ) are 0.910 and 0.090 , respectively, for roots and 0.843 and 0.157 , respectively, for shoots. The respective determined $K_{\text {pom }}$ values of ATR with seedling roots and shoots are 36.8 and 20.1 (Fig. 3). From the measured ATR concentrations in plants and nutrient solution in treatments without $\mathrm{Cd}^{2+}$, the BCF of ATR with shoots (3.46) and roots (4.86) were obtained. With the above data, the determined $\alpha_{\mathrm{pt}}$ values for ATR with shoots and roots were 0.93 and 1.16 , respectively, indicating that the ATR concentrations in plants and nutrient solution are essentially at equilibrium.

Since the presence of $\mathrm{Cd}^{2+}$ in solution enhanced the ATR concentrations in shoots and roots (Table 2), the related BCF for ATR increased accordingly, with the greatest increase up to four times with roots at solution ATR concentration of $0.5 \mu \mathrm{M}$ and solution $\mathrm{Cd}^{2+}$ of $1 \mu \mathrm{M}$ (Table 4). Consequently, these BCFs led to greater $\alpha_{\mathrm{pt}}$ values (2-4) for ATR when $\mathrm{Cd}^{2+}$ was present. The

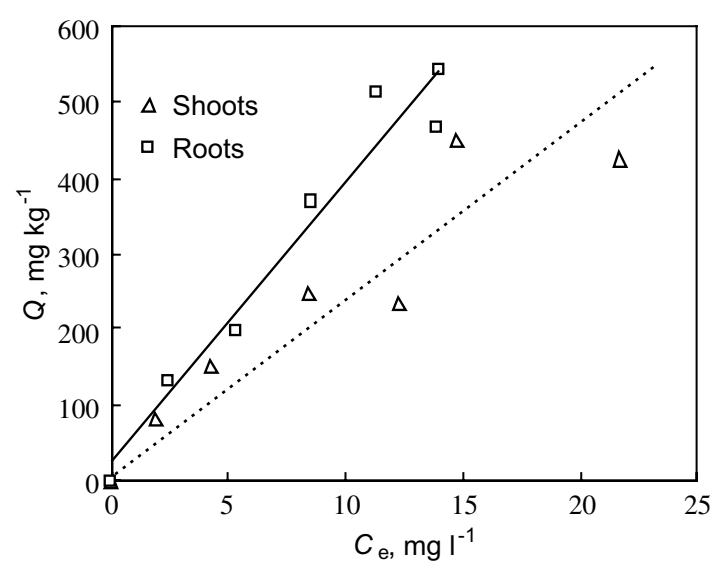

Fig. 3. ATR sorption on cut-dry rice seedlings $(Q)$ in relation to its equilibrium concentration in nutrient solution $\left(C_{\mathrm{e}}\right)$. greater $\mathrm{BCF}$ and $\alpha_{\mathrm{pt}}$ values are phenomenal because they have not been found with other nonionic compounds in the absence of significant concentrations of $\mathrm{Cd}^{2+}$ or other heavy metals (Su and $\mathrm{Zhu}, 2005$ ). With this consideration, there appear to be some type of molecular association between ATR and $\mathrm{Cd}^{2+}$ that promotes the uptake of ATR by rice seedlings.

The earlier study indicates that $\mathrm{Mg}^{2+}, \mathrm{Ca}^{2+}, \mathrm{Cd}^{2+}$, $\mathrm{Zn}^{2+}$, and $\mathrm{Pb}^{2+}$ can potentially complex with either monomeric or dimeric atrazine to form both anhydrous and hydrated (one or two waters) complex forms (Meng and Carper, 2000):

$n($ atrazine $)+m($ water $)+\mathrm{M}^{2+} \Rightarrow$ complex $^{2+}$

where $n=1$ or 2 , and $m=0,1$, or 2 . The enthalpies of formation for anhydrous metal-atrazine complexes follow the order: $\mathrm{Zn}^{2+}<\mathrm{Mg}^{2+}<\mathrm{Ca}^{2+}<\mathrm{Cd}^{2+}<\mathrm{Pb}^{2+}$. Adding either 1 or 2 stoichiometric water molecules to the metal-atrazine complex changes the formation order to $\mathrm{Ca}^{2+}<\mathrm{Mg}^{2+}<\mathrm{Zn}^{2+}<\mathrm{Cd}^{2+}<\mathrm{Pb}^{2+}$. The enthalpies of formation for metal-diatrazine complexes are in the order: $\mathrm{Ca}^{2+}<\mathrm{Mg}^{2+}<\mathrm{Pb}^{2+}<\mathrm{Zn}^{2+}<\mathrm{Cd}^{2+}$, regardless of the degree of hydration. There is no apparent effect of the ionic radii for divalent metal ions on the order of the formation enthalpies. Therefore, $\mathrm{Cd}^{2+}$ should be a more powerful metal ion to complex with any form of ATR than $\mathrm{Ca}^{2+}$ and $\mathrm{Mg}^{2+}$ ions, the latter being present in large quantities in nutrient solution. As described earlier, $\mathrm{Cd}^{2+}$ in external solution has a strong stimulating effect on the accumulation of ATR in roots and shoots (Fig. 2), with the extent of stimulation depending on the ATR-Cd ${ }^{2+}$ ratio in solution. Evidently, the ATR$\mathrm{Cd}^{2+}$ complexes formed in excess of unassociated ATR in the seedlings gave rise to the high apparent $\mathrm{BCF}$ and $\alpha_{\mathrm{pt}}$ values. Furthermore, the results suggested that the ATR $-\mathrm{Cd}^{2+}$ complexes formed in shoots/roots (and/ or in nutrient solutions) were effectively broken up by the sample extraction and treatment procedures used for the ATR analysis.

Table 4

Bioconcentration factors $(\mathrm{BCF})$ and quasi-equilibrium factors $\left(\alpha_{\mathrm{pt}}\right)$ of ATR with rice seedlings exposed to various concentrations of $\operatorname{ATR}(\mu \mathrm{M})$ and $\mathrm{Cd}(\mu \mathrm{M})$ in nutrient solution (mean $\pm \mathrm{SE}, n=4)$

\begin{tabular}{|c|c|c|c|c|c|c|c|}
\hline \multirow{2}{*}{$\begin{array}{l}\text { ATR conc. in } \\
\text { solution }(\mu \mathrm{M})\end{array}$} & & \multicolumn{3}{|l|}{ Roots } & \multicolumn{3}{|l|}{ Shoots } \\
\hline & $\begin{array}{l}\text { Cd conc. }(\mu \mathrm{M}) \\
\mathrm{BCF} \\
\alpha_{\mathrm{pt}}\end{array}$ & $\begin{array}{l}0.0 \\
4.94 \pm 0.74 \\
1.17 \pm 0.17\end{array}$ & $\begin{array}{l}0.5 \\
11.1 \pm 0.86 \\
2.62 \pm 0.20\end{array}$ & $\begin{array}{l}1.0 \\
17.6 \pm 2.14 \\
4.17 \pm 0.51\end{array}$ & $\begin{array}{l}0.0 \\
3.62 \pm 0.46 \\
0.90 \pm 0.11\end{array}$ & $\begin{array}{l}0.5 \\
5.20 \pm 0.38 \\
1.29 \pm 0.09\end{array}$ & $\begin{array}{l}1.0 \\
6.52 \pm 0.11 \\
1.62 \pm 0.28\end{array}$ \\
\hline 1.0 & $\begin{array}{l}\text { Cd conc. }(\mu \mathrm{M}) \\
\mathrm{BCF} \\
\alpha_{\mathrm{pt}}\end{array}$ & $\begin{array}{l}0.0 \\
5.21 \pm 0.60 \\
1.23 \pm 0.14\end{array}$ & $\begin{array}{l}0.5 \\
13.8 \pm 2.98 \\
3.26 \pm 0.71\end{array}$ & $\begin{array}{l}1.0 \\
7.91 \pm 0.88 \\
1.87 \pm 0.21\end{array}$ & $\begin{array}{l}0.0 \\
3.86 \pm 0.19 \\
0.96 \pm 0.05\end{array}$ & $\begin{array}{l}0.5 \\
9.07 \pm 0.65 \\
2.12 \pm 0.16\end{array}$ & $\begin{array}{l}1.0 \\
4.51 \pm 0.56 \\
1.12 \pm 0.14\end{array}$ \\
\hline 2.0 & $\begin{array}{l}\text { Cd conc. }(\mu \mathrm{M}) \\
\mathrm{BCF} \\
\alpha_{\mathrm{pt}}\end{array}$ & $\begin{array}{l}0.0 \\
4.76 \pm 0.21 \\
1.13 \pm 0.05\end{array}$ & $\begin{array}{l}0.5 \\
- \\
-\end{array}$ & $\begin{array}{l}1.0 \\
- \\
-\end{array}$ & $\begin{array}{l}0.0 \\
3.42 \pm 0.17 \\
0.85 \pm 0.04\end{array}$ & $\begin{array}{l}0.5 \\
- \\
-\end{array}$ & $\begin{array}{l}1.0 \\
- \\
-\end{array}$ \\
\hline
\end{tabular}


At ATR- $\mathrm{Cd}^{2+}$ ratios of 1 , where the ATR concentrations with both shoots and roots are less, the apparent BCF and $\alpha_{\mathrm{pt}}$ values are therefore similarly lower. The lesser apparent BCF and $\alpha_{\mathrm{pt}}$ values are well related to the greater biomass, the latter being related in turn to the greater attenuation of the combined ATR and $\mathrm{Cd}^{2+}$ toxicities. Thus, the lesser ATR uptake concentrations (and the related $\mathrm{BCF}$ and $\alpha_{\mathrm{pt}}$ values) at ATR $-\mathrm{Cd}^{2+}$ ratios of 1 , might result partially from the dilution effect due to plant growth. Another potential contribution to the observed differences in apparent BCF of ATR would be the speciation of ATR (i.e., the relative fractions of ATR and ATR $-\mathrm{Cd}^{2+}$ complexes) in both nutrient solution and within plant tissues. However, this effect remains to be clarified with a more decisive analytical technique, yet to be established.

\section{Conclusions}

The results from this study showed that either $\mathrm{Cd}^{2+}$ or ATR alone was more toxic than their mixtures to rice seedlings. The relations between the concentrations of $\mathrm{Cd}^{2+}$ and ATR with seedlings varied with their ratios in growth medium. $\mathrm{Cd}^{2+}$ enhanced the accumulation of ATR by seedlings and the enhancement is less at ATR: $\mathrm{Cd}^{2+}$ ratios of 1 in the medium. At ATR: $\mathrm{Cd}^{2+}$ ratio of 1 , the seedlings showed more gains in biomass and the observed ATR concentrations in seedlings were notably less. In the absence of $\mathrm{Cd}^{2+}$ in solution, the observed ATR concentrations with roots/shoots were close to equilibrium with the corresponding concentrations in nutrient solution to which the seedling roots were exposed for four weeks. The observed BCF of ATR with seedling roots and shoots in the absence of $\mathrm{Cd}^{2+}$ served as a useful reference to evaluate the apparent BCF of ATR in the presence of $\mathrm{Cd}^{2+}$ in nutrient solution. The relatively high apparent $\mathrm{BCF}$ observed for ATR in presence of $\mathrm{Cd}^{2+}$ were attributable to the formation of ATR $-\mathrm{Cd}^{2+}$ complexes that could be recovered from analytical procedures.

\section{Acknowledgements}

This research was financially supported by the Ministry of Science and Technology (2002CB410808) and the Chinese Academy of Sciences (KZCX3-SW-431 and Hundred Talents Program).

\section{References}

Belluck, D.A., Benjamin, S.L., Dawson, T., 1991. Groundwater contamination by atrazine and its metabolites: risk assessment, policy, and legal implications. Ann. Proc., 254-273.
Bennett, D.H., Kastenberg, W.E., McKone, T.E., 1999. A multimedia, multiple pathway risk assessment of atrazine: the impact of age differentiated exposure including joint uncertainty and variability. Reliab. Eng. Syst. Safety 63, 185-198.

Briggs, G.G., Bromilow, R.H., Evans, A.A., 1982. Relationship between lipophilicity and root uptake and translocation of non-ionised chemicals by barley. Pest. Sci. 13, 495-504.

Burkart, M.R., Kolpin, D.W., 1993. Hydrologic and land-use factors associated with herbicides and nitrate in near-surface aquifers. J. Environ. Qual. 22, 646-656.

Chiou, C.T., Sheng, G., Manes, M., 2001. A partition-limited model for the plant uptake of organic contaminants from soil and water. Environ. Sci. Technol. 35, 1437-1444.

Di Toppi, L.S., Lambardi, M., Pazzagli, L., Cappugi, G., Durante, M., Gabbrielli, R., 1998. Response to cadmium in carrot in vitro plants and cell suspension cultures. Plant Sci. 137, 119-129.

Finley, B.L., Mayhall, D.A., Scott, P.K., 1994. Development of a standard soil-to-skin adherence probability density function for use in Monte Carlo analysis of dermal exposure. Risk Anal. 14, 555-569.

Gu, J.G., Fan, Y.Z., Gu, J.D., 2003. Biodegradability of atrazine, cyanazine and dicamba under methanogenic condition in three soils of China. Chemosphere 52, 1515-1521.

Hirschberg, J., McIntosh, L., 1983. Molecular basis of Herbicide resistance in Amaranthus hybridus. Science 222, 13461349.

Katz, I., Green, M., Ruskol, Y., Dosoretz, C.G., 2000. Characterization of atrazine degradation and nitrate reduction by Pseudomonas sp. strain ADP. Adv. Environ. Res. 4, 219-224.

Li, H., Sheng, G.Y., Sheng, W.T., Xu, O.Y., 2002. Uptake of trifluralin and lindane from water by ryegrass. Chemosphere 48, 335-341.

Liu, C., Bennett, K.H., Kastenberg, W.E., McKone, T.E., Browne, D., 1999. A multimedia, multiple pathway exposure assessment of atrazine: fate, transport and uncertainty analysis. Reliab. Eng. Syst. Safety 63, 169-184.

Martin, M., Hagege, A., Brunette, J.P., Leroy, M., 1998. Use of synergistic extraction for the study of atrazine/metal interactions. Anal. Chim. Acta. 373, 161-165.

McKone, T.E., Bogen, K.T., 1991. Predicting the uncertainties in risk assessment. Environ. Sci. Technol. 25, 1674 1681.

McLaughlin, M.J., Singh, B.R., 1999. Cadmium in soil and plants: A global perspective. In: McLaughlin, M.J., Singh, B.R. (Eds.), Cadmium in Soil and Plants. Kluwer Academic Publishers, Dordrecht, The Netherland, pp. 13-21.

Meng, Z., Carper, W.R., 2000. Effects of hydration on the molecular structure of metal ion-atrazine dimer complexes: A MOPAC(PM3) study. J. Mol. Struct. (Theochem) 531, 89-98.

Sielken, R.L., 1987. Cancer dose-response extrapolations. Environ. Sci. Technol. 21, 1033-1039.

Shimabukuoro, R.H., Swanson, H.R., Walsh, W.C., 1970. Glutathione conjugation: Atrazine detoxication mechanism in corn. Plant Physiol. 46, 103-107.

Su, Y.H., Zhu, Y.G., 2005. Bioconcentration of atrazine and chlorophenols into roots and shoots of rice seedlings. Environ. Pollut., accepted. 
Trapp, S., 2004. Plant uptake and transport models for neutral and ionic chemicals. Environ. Sci. Pollut. Res. 11, 33-39.

Trapp, S., Matthies, M., 1995. Generic one-compartment model for uptake of organic chemicals by foliar vegetation. Environ. Sci. Technol. 29, 2333-2338.

Trostle, C.L., Bloom, P.R., Allan, D.L., 2001. HEDTAnitrilotriacetic acid chelator-buffered nutrient solution for zinc deficiency evaluation in rice. Soil Sci. Soc. Am. J. 65, 385-390.

Weiss, P., 2000. Vegatation/soil distribution of semivolatile organic compounds in relation to their physicochemical properties. Environ. Sci. Technol. 34, 1707-1714.
Wiegand, C., Pflugmacher, S., Giese, M., Frank, H., Steinberg, C., 2000. Uptake, toxicity and effects on detoxication enzymes of atrazine and trifluoroacetate in embryos of Zebrafish. Ecotoxicol. Environ. Safety 45, 122-131.

Zhao, Z.Q., Zhu, Y.G., Li, H.Y., Smith, S.E., Smith, F.A., 2003. Effects of forms and rates of potassium fertilizers on cadmium uptake by two cultivars of spring wheat (Triticum aestivum L.). Environ. Int. 29, 973-978.

Zhu, Y.G., Shaw, G., Nisbet, A.F., Wilkins, B.T., 1999. Effect of external potassium on compartmentation and flux characteristics of radiocaesium in intact spring wheat roots. Ann. Botany 84, 644-659. 